\title{
Occupational Situation of the Rural Farming and Landless Population in Poland in 2002-2016
}

\begin{abstract}
The Polish rural population is highly differentiated in terms of occupational situation, mainly because of the rural population's involvement in individual farming. The purpose of this paper is to investigate the occupational situation of the rural farming and landless population in 2002, 2016 and 2017 in the context of non-farming job opportunities and unemployment risks. The study consists of two parts; the first one analyses the changes to the occupational situation of the rural population in the labour market; the second one identifies the risk of unemployment in selected groups of rural population. Aggregated weighted data and non-aggregated, non-published non-weighted BAEL (Polish LFS) data was used as source material. The study period witnessed a considerable improvement of the rural population's occupational situation. However, if there is a slowdown in economic growth, the occupational situation of the rural population may deteriorate. In the short and medium term, people involved in individual farming and landless woman, i.e. the group where the real unemployment rate is much lower than equilibrium unemployment, will be particularly severely affected. In the longer term, the adverse impact of business cycles may also deteriorate the situation of landless men if their equilibrium unemployment level "follows" the real unemployment rate.
\end{abstract}

Key words: labour force, rural areas, natural unemployment rate

JEL Classification: J21, J11

\section{Introduction}

The Polish rural population is highly differentiated in terms of occupational situation, which is mainly caused by the rural population's involvement in individual farming (Frenkel, 2013; Kołodziejczak, 2018). This is because the traditional model of individual farming, based on the fragmented structure of farms, was existing over decades. It was supplemented by largescale agricultural holdings, based on the state or cooperative property. The occupational status of the rural population was also strongly impacted by the political and economic transformation: from 1989 to 2002 primarily by the economic restructuring; and afterwards mainly by the uneven distribution of investments. In the transformation period, the Polish rural areas absorbed a considerable part of surplus labour force released from the industrial and mining sector. Some agricultural household members employed both within and outside agriculture (referred to as biprofessional workers or worker-farmers) have lost their non-agricultural jobs. Blue-collar workers and miners also went back to their family farms. That group migrated to urban areas during the industrial and mining boom; after losing their jobs, they found themselves with no livelihood. As a consequence, the costs of living of household members who lost their nonagricultural income put an additional economic burden on individual farms (Kołodziejczak and Wysocki, 2015). At the same time, the winding-up of nearly all state-owned and cooperative farms resulted in increasing the number of unemployed rural landless. They found themselves in

${ }^{1}$ Ph.D., Poznań University of Life Sciences, Department of Finance and Accounting, ul. Wojska Polskiego 28 60-637 Poznań, e-mail: wkol@up.poznan.pl; https://orcid.org/0000-0001-7315-6717 
a particularly difficult situation: with no job opportunities, the transfers (benefits, allowances etc.) became their only livelihood option.

After Poland accessed the European Union in 2004, the situation of rural areas started to improve. This was particularly beneficial to the farming population but also to the landless (because of investment booms and a reduction of the general unemployment level). However, the occupational status of the rural population continues to be strongly diversified, and there is an income gap between individual farming and non-agricultural sectors.

The structural changes to the rural population's economic activity are a difficult process, mainly because of the limited number of jobs on a countrywide basis, the distance of jobs from rural areas and the fact that the rural population is less educated than urban dwellers (or that their skills profile does not match the employers' expectations). However, this is a continuous process which is driven by the national economic development, the generational shift in rural areas and the opening of western countries' labour markets, and which has gained significant momentum after Poland's accession to the European Union (Polska wieś, 2018).

The purpose of this paper is to investigate the occupational situation of the rural farming and landless population in 2002, 2016 and 2017 in the context of non-farming job opportunities and unemployment risks.

\section{Research method and materials}

The study consists of two parts; the first one analyses the changes to the occupational situation of the rural population in the labour market; the second one identifies the risk of unemployment in selected groups of rural population based on a comparison between the estimated equilibrium unemployment rate and the real unemployment rate.

The first part of the study relied on descriptive analysis methods and on indices of the population's economic activity based on data from the Labour Force Survey conducted by the Central Statistical Office in 2002 and 2017.

In the second part, the equilibrium unemployment rate was calculated for the rural population both connected and not connected to individual farming, and was compared to the real unemployment level. To do so, the method for estimating the natural (equilibrium) employment level proposed by the Centre for Economic Policy Research (Unemployment $1995)^{2}$ was used. The analysis was based on individual, non-weighted quarterly raw data from the 2016 Polish LFS. Changes in economic activity of individuals were observed in panels, i.e. pairs of quarters such that from the entire LFS sample, account is taken only of operators

\footnotetext{
${ }^{2}$ Depending on the applied method estimating equilibrium unemployment they may be determined for the entire economy or for individual groups of the population distinguished based on selected characteristics. Models based on the Philips Curve theory or on the hypothesis of rational expectations and neutrality of money, e.g. NAIRU (Non-Accelerating Inflation Rate of Unemployment) and NAWRU (Non-Accelerating Wage Rate of Unemployment) use market variables and their application is limited generally to aggregate data at the level of whole economies (Socha and Wojciechowski, 2004). Methods based on the analysis of changes in behavior of individuals on the labor market make it possible to analyze separately groups of the population differing in socioeconomic characteristics. The most important of these include the method proposed by the Center for Economics Policy Research (CEPR) (Unemployment 1995), the Gärtner method (1997) and the method proposed by Darby, Haltiwanger and Plant (1986).
} 
surveyed in both quarters of the pair under consideration (e.g. 1Q and 2Q 2016, and then 2Q and 3Q 2016, and 3Q and 4Q 2016). Four non-published individual quarterly aggregates of raw LFS data from 2016 were used. After removing urban population data from the database and identifying the operators recorded in two subsequent quarters, ca. 20,000 rural dwellers were subjected to examination (with the initial size of the quarterly LFS sample being around 100,000). To improve the quality of results (primarily to reduce the risk of incidental observations), quarterly panels were aggregated into a single yearly panel which served as a basis for further calculations. Of the many possible classification breakdowns (including age, gender, education, place of residence, town class, relation to agriculture etc.), this paper presents the results obtained for three criteria used simultaneously: town class (village), relation to agriculture and gender. Non-weighted data was used in calculations; this is the only possible approach to individual LFS data because weights assigned to respondents by the Central Statistical Office are appropriate only for the sample as a whole and are not applicable to identified population groups. Therefore, the results should be regarded as approximate figures. Their informative value consists in the identification of gaps and possible trends but they cannot be considered as precise true values.

LFS data was used to determine the volume and rate of flows between particular economic activity statuses of the population in 2000-2005, 2006-2009 (average levels) and 2016. This enabled the use of the equilibrium unemployment estimation method developed by the Centre for Economics Policy Research (CEPR) (Unemployment 1995). The CEPR method consists in determining the equilibrium unemployment rate as follows:

$$
u^{*}=\frac{s+z}{s+h+n}
$$

where:

$\mathrm{u}^{*}$ - equilibrium (steady-state) unemployment rate,

$\mathrm{s}=(\mathrm{EU}+\mathrm{EN}) / \mathrm{E}-$ rate of outflow from employment (including to unemployment and economical inactivity),

$\mathrm{h}=\mathrm{UE} / \mathrm{U}-$ rate of outflow from unemployment to employment,

$\mathrm{z}=(\mathrm{NU}-\mathrm{UN}-\mathrm{EN}) /(\mathrm{E}+\mathrm{U})-$ demographic component of unemployment,

$\mathrm{n}$ - percentage changes in labour force resources in the assumed sample duration,

while:

$\mathrm{E}$ - the number of employed at the beginning of the investigated period,

$\mathrm{U}$ - the number of unemployed at the beginning of the investigated period,

$\mathrm{EU}$ - the volume of flows from employment to unemployment in the analysed period (the number of individuals, who changed their status from employed to unemployed),

EN - the volume of flow from the group of employed to the group of economically inactive,

$\mathrm{NU}$ - the volume of flow from the group of economically inactive to the group of unemployed,

$\mathrm{UN}$ - the volume of flow from the group of unemployed to the group of economically inactive,

UE - the volume of flow from the group of unemployed to the group of employed.

If $\mathrm{u}^{*}>\mathrm{u}$, actual unemployment $(\mathrm{u})$ will probably increase, since it did not yet reach the level resulting from the effect of structural factors on the labour market (mismatch of supply and 
demand for labour); if $u^{*}<u$, actual unemployment is greater than that resulting from structural factors and the difference may be approximately treated as equivalent to unemployment caused by a too slow economic growth (thus probably values $u$ may approach level $u^{*}$ by stimulating the economic prosperity on the market for goods and services). The analysis of changes in values of these indexes for individual groups of the population distinguished from the labour resources or for individual markets makes it possible to determine causes for adverse phenomena, identify problem groups at risk of unemployment and propose directions for corrective actions ${ }^{3}$.

\section{Results of the study}

Poland holds relatively large resources of labour. In the total population of 30,613 thousand people aged 15 and more covered by the 1Q 2017 LFS, rural inhabitants represented 39.8\% (12,171 thousand) (Labour force survey 2017). A considerable part of the rural population are directly or indirectly involved in agriculture; for many decades, that sector has traditionally supported the livelihoods of rural households. From 1989, the share of agricultural employees in the total population employed in the national economy has consistently decreased. In 1989, it was 28.6\% (Puzio-Wacławik, 2006). The respective levels for 2002 and 1Q 2017 were 17.6\% and barely 10.3\% (Labour force survey 2017).

Figure 1 shows the distribution of the rural population in 2002-2017 by relation to agriculture and by economic activity. In the total rural population aged 15 and more (11,512 thousand), the farming population was dominant with a share of $57.5 \%$ in 2002 . However, by 2016 it was only $31.4 \%$ (a decrease by 26.1 percentage points). This had a considerable impact on the occupational situation of these groups. As may be noticed, in 2017, there was less non-farming unemployed and much more employed people than in 2002. The number of economically inactive people more than halved in the group connected to farms, and grew by more than 1.7 times in the in the group not connected to farms. Thus, while the agricultural sector was partially "cleaned" of inactive individuals (which is a positive development), the growing number of economically inactive landless people means the problem was just pushed away rather than solved. This is partially due to the generational shift, i.e. economic deactivation of retired farmers who sold/transferred their farms. However, the structure of this process is considerably affected by a high rate of inactivity among working-age women (Kołodziejczak, 2018). The matter of major

\footnotetext{
${ }^{3}$ It needs to be stressed that they are oversimplifications and the interpretation of the results based on these assumptions has to take into consideration economic and social conditions. However, it is worthwhile to accept them in view of their usefulness. Limitations observed in this respect result first of all from the mechanisms of hysteresis on the labor market. Cf (Layard, Nickell, Jackman 1991, Kołodziejczak and Wysocki, 2013).

${ }^{4}$ The general improvement of the labor market situation on a countrywide basis enabled a clear increase of the number and share of employed persons. However, as regards women, economic inactivity continued to be the main problem. This could be partially explained by: the nature of farming work (men usually handle physically demanding tasks and operate the machinery); the option not to declare farming employment by women who manage the farmers' households (despite their actual involvement in farm management); the women's longer average life expectancy (i.e. their higher share in the group of persons of retiring age); and the popularity of the traditional family model in rural areas where women run the households and raise children while the responsibility of men is to earn a livelihood for their families. Note also that for many women, it is economically unviable to take up a job. This means cases where the expected income is lower or slightly higher than the costs involved in taking up the job. After considering the increase of living costs related to employment; children care; time lost;
} 
importance for the growth of employment and reduction of unemployment in the study period was the growing number of jobs resulting from economic development. The 20032005 period marked the beginning of improvements to employment figures which is seemingly related to the economic recovery that accompanied Poland's accession to the EU. In parallel, economic deactivation levels continued to follow a slight upward trend until 2008 (this was due to demographic factors and legislative measures which allowed the employees to retire before regular retirement age). However, in 2009, the economic activity rate also started to grow, despite the simultaneous increase of the population's average age (Kołodziejczak, 2018). Currently, more and more attention is paid to the shortage of labour force which affects the economy, especially the agriculture, and is filled with immigrants from other countries, mainly Ukraine (Górny and Kaczmarczyk, 2018). The shortages do not exclude excess employment in the agricultural sector because the average level of agricultural employment varies from one voivodship to another and depends on such farm characteristics as their area, lines of production, technological and organizational level etc.

Excess employment may be caused by technological or socio-economic factors. As regards technological reasons, high levels of employment are justified by the need to run agricultural production processes even though it is economically unviable. In this case, costeffectiveness may be improved by upgrading the technology, replacing the machinery, merging fragmented land or using production services instead of own labour resources. When it comes to socio-economic reasons, the social role of individual farms is the key factor. In this case, cost-inefficiency (or even technical inefficiency) will not result in employment reduction or farm restructuring because the farming population lack the capacities or skills which are necessary to upgrade their farms or engage in non-agricultural employment ${ }^{5}$.

Figure 2 characterizes the occupational situation of the Polish population grouped by place of residence and relation to agriculture (in the case of rural dwellers) in 2002 and 2017. It can be noted that both in 2002 and 2017 the occupational situation of population in rural areas was slightly better than population in urban areas. while in 2012 was generally similar for the urban and rural population, in 2017 it was much better for the rural population. However, there was a clear difference in the labour force participation rate, employment rate and unemployment rate between the rural population connected with individual farms and the landless population. Most importantly, the labour force participation rate was considerably lower for the landless in both years covered by the analysis. Also, a much lower employment rate and a twice as high

and the partial loss of social benefits, it may turn out that the woman's job fails to provide any material benefits for the household (2018).

${ }^{5}$ Rembisz (2016) claims that in the agriculture sector, remunerations are much higher than labor productivity while it is the opposite for other sectors. The reasons could be the excessive employment in the Polish agriculture sector and the fact that the remunerations of agricultural employees include transfers made under the CAP. The author believes that the proposed method for improving agricultural labor productivity by partially releasing the workforce to nonagricultural sectors does not contradict the paradigm of sustainable agricultural development in a Pareto sense, as described by Czyżewski (2012); instead, it only indicates that the commitment to socio-economic sustainability of rural areas needs to be properly understood. Agricultural sustainability should not be opposed to labor efficiency (which is obvious when increasing the farms' turnover with transfers) but must be based on sound structural foundations. Only the commitment to seek a natural equilibrium of the system may provide long-lasting results. In turn, establishing a fake socio-economic balance of rural areas based on continuous financing is a costly process, even for the wealthy (but indebted) EU-15 countries, and faces increased political resistance from EU states. Also, this system perpetuates the adverse developments affecting the economic activity of the rural population, especially hidden unemployment and professional deactivation (for economically unviable farms, CAP transfers play a role similar to unemployment benefits, and therefore discourage the farmers from implementing any changes). 
unemployment rate was recorded for that group. Therefore, although the general occupational situation of rural dwellers has clearly improved, the landless population continues to face difficulties in the labour market. Note however that the above also results from the size of labour force "released" from the agricultural sector (which increased the landless population) and from the progressing suburbanization of rural areas adjacent to large urban centres".

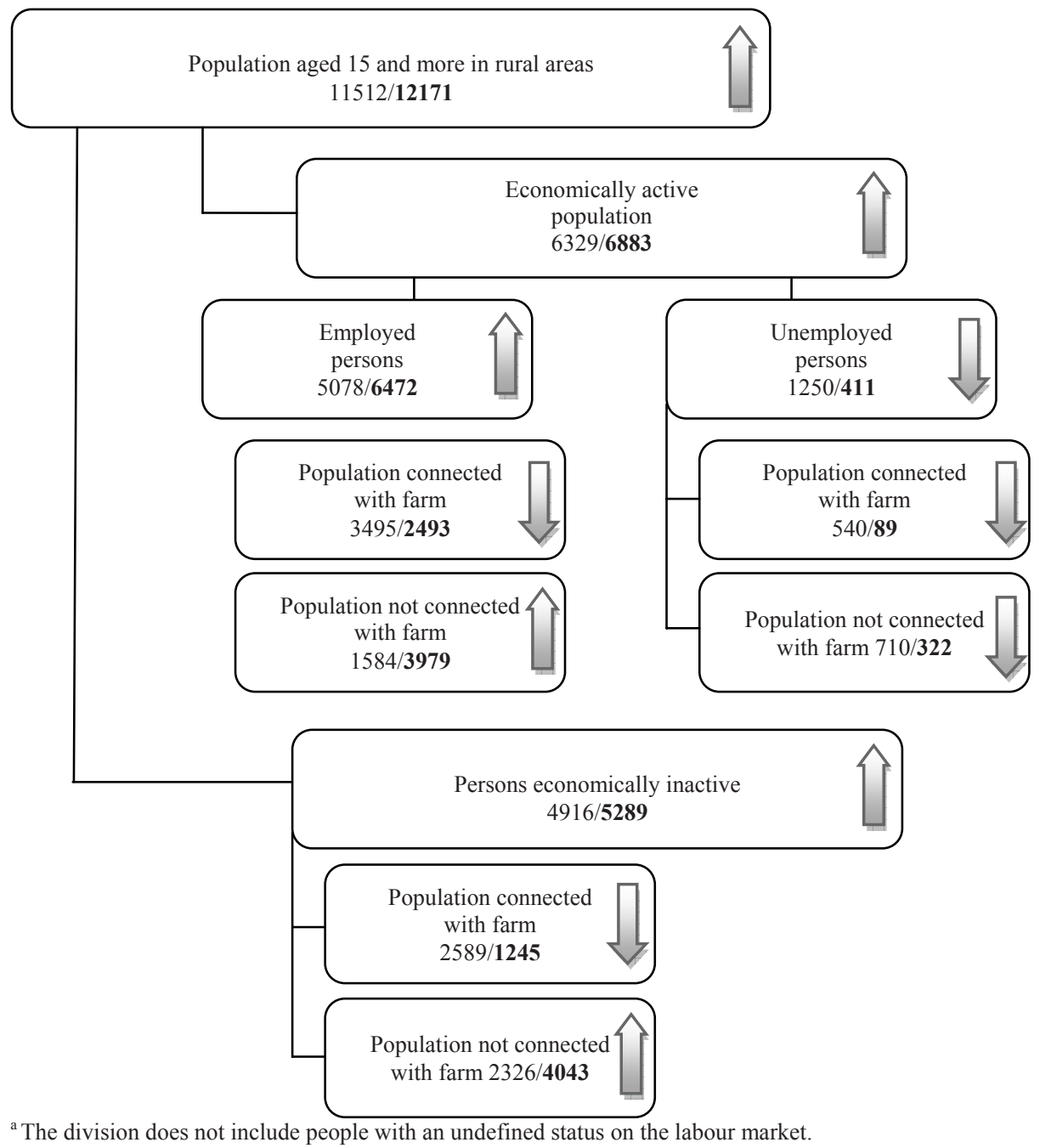

Fig. 1. Population aged 15 and more in rural areas by connection with agricultural farm and economic activitya (thousand peoples)

Source: Labour force survey in Poland I quarter 2017 (2017). GUS, Warszawa.

${ }^{6}$ The Polish territory is divided into "rural" and "urban" areas based on an administrative criterion. As a consequence, urban dwellers who settle in suburban areas are automatically counted in the rural population although they have no connection to agriculture. 


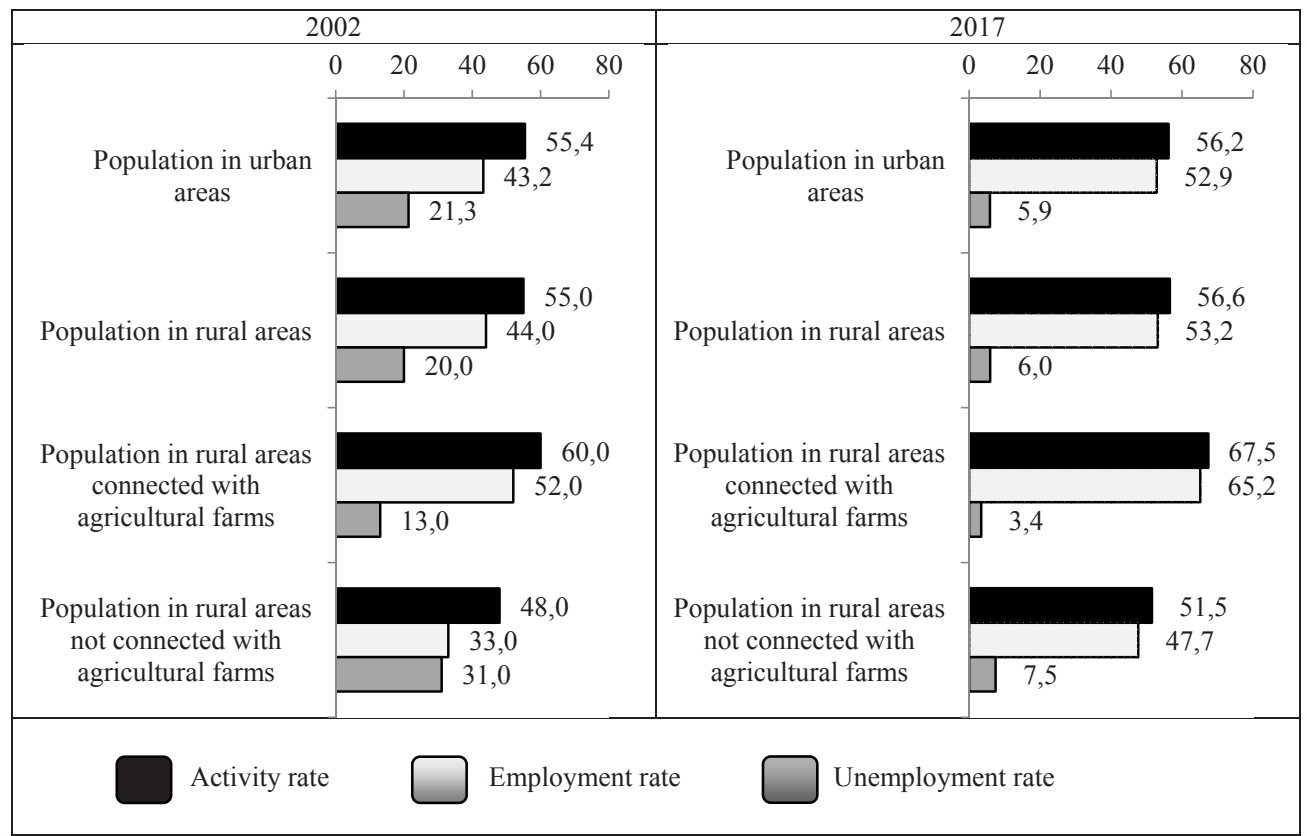

Fig. 2. Characteristics of the occupational situation of the population by place of residence and connection with agricultural farms in 2002 and $2017(\%)$

Source: Labour force survey in Poland I quarter 2017 (2017). GUS, Warszawa.

Figure 3 presents the estimated values of the equilibrium unemployment rate and the relation between real unemployment and equilibrium unemployment in rural areas for the rural population grouped by relation to agriculture and gender in 2017. The equilibrium unemployment rate is the simplest approximation of the unemployment level which the labour market tries to achieve. Therefore, this estimation provides a basis for concluding whether specific groups covered by the study are at risk of unemployment. The smallest equilibrium unemployment rate was characteristic for the rural population connected to individual farms $(6.5 \%)$ and was 1.9 times higher than real unemployment. This could suggest the real unemployment rate is likely to increase in the event of economic downturn. In turn, the equilibrium unemployment rate for the population not connected to individual farms $(9.4 \%)$ was slightly below the real unemployment rate. This means there are shrinking opportunities for improving that group's situation. A better explanation of existing patterns may be found by analysing the situation of rural inhabitants grouped by gender. In this case too, the involvement in agricultural activities was a clear differentiating factor. The equilibrium unemployment rate for men connected to individual farms $(9.4 \%)$ was higher than for landless men (6.4\%). However, at the same time, the real unemployment rate was 2.8 times lower while the real unemployment rate for landless men was slightly above the equilibrium unemployment rate. Once again, this provides grounds for concluding that the advantageous situation of rural dwellers (in this case, men) is conditioned by business cycles, and that it may severely deteriorate during the next crisis. The equilibrium unemployment rate for women connected to farms $(5.2 \%)$ was 1.8 times lower than the real unemployment rate; for landless women $(14.6 \%)$, it was 1.9 times lower 
than the real unemployment rate. Thus, unlike in the case of men, while the connection to agriculture did not make the advantageous occupational situation dependent upon business cycle fluctuations, it did protect women (just like men) against unemployment.

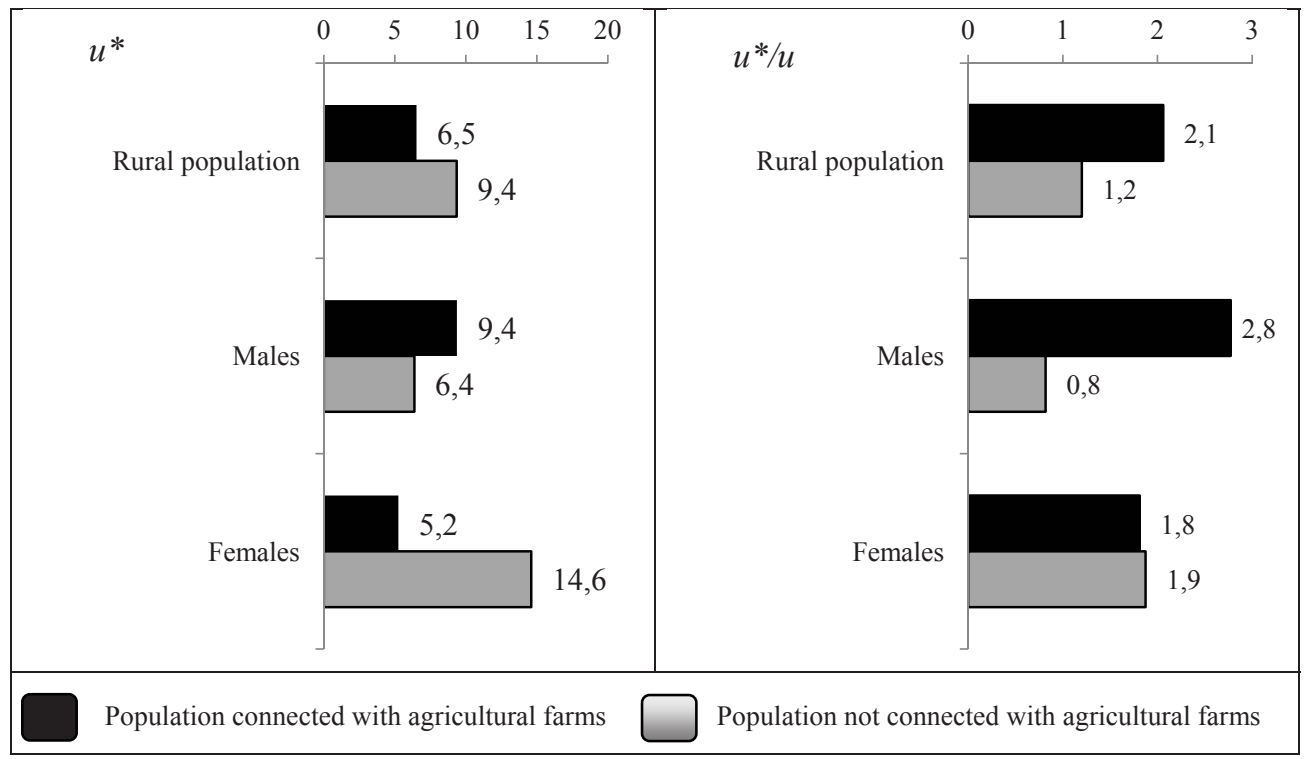

Fig. 3. Rate of equilibrium unemployment $\left(\mathrm{u}^{*}\right)$ and relation between equilibrium unemployment and real unemployment $\left(\mathrm{u}^{*} / \mathrm{u}\right)$ in rural areas by connection with agricultural farms and sex in $2016(\%) *$

* Because the calculation was made on the basis of unweighted data, received results cannot be directly compared to those presented in figure 2 .

Source: the author's calculations based on unpublished, individual quarterly raw data of Polish LFS (BAEL).

\section{Summary}

The purpose of this paper was to investigate the occupational situation of the rural farming and landless population in 2002, 2016 and 2017 in the context of non-farming job opportunities and unemployment risks.

1) The study period witnessed a considerable improvement of the rural population's occupational situation. This was primarily reflected by the increasing employment and decreasing unemployment levels, whether in absolute terms or expressed as the labour force participation rate and unemployment rate. These changes were accompanied by a decrease in excess employment in the agriculture through the reduction of the share of agricultural employees in the total population employed in the national economy. These advantageous developments were primarily driven by economic growth and the opening of labour markets of EU-15 countries following Poland's accession to the EU.

2) Although the general occupational situation of rural dwellers has clearly improved, the landless population continues to face difficulties in the labour market. Note that the labour force participation rate and the employment rate were clearly lower for the rural population 
not connected to individual farms than for the farming population; it was the opposite for the unemployment rate.

3) Over the study period, the agricultural sector was partially "cleaned" of inactive individuals connected to individual farms (which is a positive development). However, the growing number of economically inactive landless people means the problem was just pushed away rather than solved. This is partially due to the generational shift, i.e. economic deactivation of retired farmers who sold/transferred their farms. However, the structure of this process is considerably affected by a high rate of inactivity among working-age women.

4) The low levels of real unemployment among the population connected to individual farms largely result from economic prosperity. However, high unemployment rates recorded for this group suggest that unemployment may rise considerably in the event of an economic slowdown. For the landless, real unemployment is close to equilibrium employment which means it primarily depends on structural determinants. Only for landless women the equilibrium unemployment level was nearly twice the real unemployment rate. The probable factors contributing to this situation are the labour market programs for women (which improve their occupational status) as well as the impacts of women's competitive disadvantage in the labour market and the fact that women are at a greater risk of economic inactivity.

5) As shown by the results, if there is a slowdown in economic growth, the occupational situation of the rural population may deteriorate. In the short and medium term, people involved in individual farming and landless woman, i.e. the group where the real unemployment rate is much lower than equilibrium unemployment, will be particularly severely affected. In the longer term, the adverse impact of business cycles may also deteriorate the situation of landless men if their equilibrium unemployment level "follows" the real unemployment rate.

6) The author believes the impacts of the above threats may be mitigated by establishing a sound structural framework, especially through the continued release of excess labour force from the agriculture to non-agricultural sectors. In order for this to happen, three cumulative conditions must be met: restructuring and modernization of farms which enable a reduction of the workforce without adverse impacts on production; a sufficient demand for labour outside agriculture which must geographically match the existing rural labour resources; and a qualitative match between labour supply and demand.

\section{Acknowledgements}

The paper is funded by the National Science Centre within the MINIATURA research project No. NCN DEC-2017/01/X/HS4/00565, entitled "Determinants of Economic Activity of the Rural Population in Poland. Opportunities to reduce hidden unemployment in agriculture" (Determinanty aktywności ekonomicznej ludności wiejskiej w Polsce. Możliwości redukcji bezrobocia ukrytego w rolnictwie). 


\section{Bibliography}

Czyżewski, B. (2012). Produktywność zasobów w rolnictwie w Polsce wobec paradygmatu zrównoważonego rozwoju (Resource productivity in Polish agriculture in the context of the sustainable development paradigm). Studia Ekonomiczne, 2(LXXIII), 165-188.

Darby, M., Haltiwanger, J., Plant, M. (1986). Unemployment Rate Dynamics and Persistent Unemployment under Rational Expectations. American Economic Review 75(4), 1-55.

Frenkel, I. (2013). Zatrudnienie i struktura dochodów w gospodarstwach rolnych w latach 2005-2010 (Employment and structure of income in farms in 2005-2010). Inst. Rozw. Wsi i Roln. PAN, Warszawa.

Gärtner, M. (1997). A Primer in European Macroeconomics, Prentice Hall, London.

Górny, A., Kaczmarczyk, P. (2018). A known but uncertain path: The role of foreign labor in Polish agriculture. Journal of Rural Studies, doi.org/10.1016/j.jrurstud.2017.12.015.

Individual, non-weighted quarterly raw data from the 2016 Polish LFS (BAEL).

Kołodziejczak, W. (2018). Labour force in Polish rural areas after Poland's accession to the European Union. Proceedings of the 2018 International Conference "Economic Science For Rural Development", No 47 Jelgava, LLU ESAF, 911 May 2018, 156-163; DOI 10.22616/ESRD.2018.000

Kołodziejczak, W., Wysocki, F. (2013). Identyfikacja charakteru bezrobocia w Polsce w latach 2006-2009 (The nature of unemployment in Poland in 2006-2009). Gospodarka Narodowa, 9(265), 29-52.

Kołodziejczak, W., Wysocki, F. (2015). Determinanty aktywności ekonomicznej ludności wiejskiej w Polsce (Determinants of economic activity of the rural population in Poland). Wyd. UP w Poznaniu, Poznań.

Labour force survey in Poland I quarter 2017 (2017). GUS, Warsaw (online). Accessed on April 24, 2018.

Layard, R., Nickell, S., Jackman, R. (1991). Unemployment. Macroeconomics Performance and the Labor Market, Oxford University Press, Oxford-New York.

Polska wieś 2018. Raport o stanie wsi (Rural Poland 2018. Rural Development Report) (2018). Fundacja na rzecz Rozwoju Polskiego Rolnictwa, Wydawnictwo Naukowe Scholar, Warszawa.

Puzio-Wacławik, B. (2006). Trójsektorowa struktura zatrudnienia w Polsce na tle krajów Unii Europejskiej (Trisectoral employment structure in Poland compared to European Union countries). Scientific Journals Polish Economic Society, 4, 97-111.

Rembisz W. (2016). Relacje wynagrodzenia i wydajności czynnika pracy w rolnictwie na tle gospodarki narodowej i jej sektorów w Polsce w okresie 2005+2012 (Relationship between remunerations and labor productivity in agriculture compared to the Polish national economy and its sectors in 2005+2012), Wieś $i$ Rolnictwo, 2(171), 41-58.

Socha, M., Wojciechowski, W. (2004). Koncepcja NAIRU, dezinflacja a druga fala bezrobocia w Polsce (The NAIRU concept, disinflation and the second wave of unemployment in Poland). Bank $i$ Kredyt, 35(3), 4-15.

Unemployment: Choices for Europe (1995). CEPR London.

\section{For citation:}

Kołodziejczak W. (2018). Occupational Situation of the Rural Farming and Landless Population in Poland in 2002-2016. Problems of World Agriculture, 18(2), 156-165;

DOI: $10.22630 /$ PRS.2018.18.2.43 